\title{
Are Effective Altruists Saints? Effective Altruism, Moral Sainthood, and Human Holiness
}

\begin{abstract}
This essay explores the relationship between effective altruism, supererogation, and sainthood. In the first section I note Peter Singer's use of the term "saint" in The Most Good You Can Do (2015) and argue that it is an allusion to J. O. Urmson's classic article "Saints and Heroes" (1958), which was criticized in Singer's own classic, "Famine, Affluence, and Morality" (1972). Here Singer was primarily concerned to deflect the potential application of Urmson's defence of supererogation to certain "charitable" acts that Singer thought were obligatory, while the Urmsonian use of "saint" passed without comment. But Susan Wolf's influential "Moral Saints" (1982) rejuvenated both the term and Urmson's supererogatory emphasis, arguably requiring Singer in 2015 finally to address both together: effective altruists are not "saints" because their actions are not supererogatory. Singer and Wolf thus agree on the meaning of Urmsonian sainthood but disagree on its evaluation and exemplification. In the second section I revisit Robert Merrihew Adams's well-known response to Wolf, "Saints" (1984), and argue that Adams's concern with "real saints" as opposed to moral abstractions remains valid and opens up helpful lines of further inquiry. In addition to moving away from Urmsonian sainthood, it raises the question of why primarily secular movements such as effective altruism often have such different "hagiological intuitions" from religions such as Christianity: that is, why do the respective exemplars differ so greatly? The third section thus considers Jean Vanier (1928-2019) and his L'Arche movement as exemplars of human holiness that effective altruism would struggle to endorse or even recognize (but also noting how this claim has been undermined by posthumous revelations about Vanier). The brief conclusion raises some further implications of these various arguments about effective altruism, moral sainthood, and human holiness.
\end{abstract}

\section{Introduction}

This essay explores the relationship between effective altruism (EA), supererogation, and sainthood. In the first section, I note Peter Singer's use of the term "saint" in The Most Good You Can Do and argue that it is an allusion to J. O. Urmson's classic article "Saints and Heroes," which was criticised in Singer's own classic, "Famine, Affluence, and Morality." Here Singer denied the application of Urmson's general defence of supererogation to certain acts that Singer thought were obligatory, while the Urmsonian use of "saint" passed without comment. But then Susan Wolf's influential "Moral Saints" rejuvenated both the term and Urmson's emphasis on the supererogatory, arguably provoking Singer finally to address both together: effective altruists are not "saints" because their actions are not (in Singer's view) supererogatory. In the second section, I revisit Robert Merrihew Adams's well-known response to Wolf and argue that Adams's concern with "real saints" as opposed to moral abstractions remains valid and opens up 
helpful lines of further inquiry. In addition to moving away from moral sainthood, it raises the question of why primarily secular movements such as EA often have such different "hagiological intuitions" from religions such as Christianity: that is, why do the respective exemplars differ so greatly? The third section thus considers Jean Vanier (1928-2019) and his L'Arche movement as exemplars of human holiness that EA would struggle to endorse or even recognise. The brief conclusion notes some further implications of these arguments about EA, moral sainthood, and human holiness.

\section{Singer, Saints, and Supererogation}

The effective altruist, says Peter Singer in The Most Good You Can Do, is not necessarily a saint. To be more precise: "most effective altruists are not saints, but ordinary people like you and me, so very few effective altruists claim to live a fully ethical life. Most of them are somewhere on the continuum between a minimally acceptable ethical life and a fully ethical life." " So by "saint" here, Singer apparently means someone who lives a "fully ethical life" - whatever that might be taken to entail. He explains further that "while doing the most good is an important part of the life of every effective altruist, effective altruists are real people, not saints, and they don't seek to maximise the good in every single thing they do, 24/7. As we shall see, typical effective altruists leave themselves time and resources to relax and do what they want." 2 By contrasting "saints" with "real people" Singer is probably being facetious, but maybe not, and the ambiguity opens the genuine question of whether he thinks there actually are "saints" in the sense of those who live "a fully ethical life" and "seek to maximise the good in every single thing they do." 3 Effective altruists may not (all) be saints, but that is because, as morally impressive as they are (at least by Singer's standards), even they do not measure up to the moral stature of sainthood, thus defined. While he does not cite either one in these comments, I think

1 Singer, Most Good, viii.

2 Ibid., 8. This book was written for a broad audience rather than for professional philosophers, but is still necessary to engage with as an important defence of EA. For an account of how EA and similar ideas have made a powerful impact on a variety of people, see MacFarquhar, Strangers Drowning, published in the UK with the subtitle Voyages to the Brink of Moral Extremity and in the USA with Grappling with Impossible Idealism, Drastic Choices, and the Overpowering Urge to Help. I will cite from the American edition.

3 Leigh Vicens observed on an earlier draft of this paper that by "saint" in this context Singer seems to refer to a strictly consistent act utilitarian. 
that here Singer is implicitly alluding and responding to both J. O. Urmson and Susan Wolf.

\subsection{Singer and Urmson: Saints and Supererogation}

To begin with, simply in speaking of "saints" in this moral manner, Singer gestures toward an influential tradition in Anglophone analytic philosophy that began in 1958 with Urmson's "Saints and Heroes." Here, Urmson observed that in ordinary usage we "sometimes call a person a saint, or an action saintly, using the word 'saintly' in a purely moral sense with no religious implications." More specifically, he says, the saintly in this broad moral sense involves "resistance to desire and self-interest" whereas the heroic involves "resistance to fear and self-preservation." ${ }^{4}$ But Urmson then went on to introduce the primarily-theological concept of supererogation into secular ethical theory, and it is precisely the supererogatory that Urmson identifies with genuine sainthood in his distinctive technical sense of the term. Prior to Urmson's paper, most philosophers divided moral actions into three categories: the wrong, the neutral, and the obligatory. Outside of Roman Catholic circles, the idea that there was a potential fourth category, namely good actions that went beyond obligation, actions in which an agent did more than was morally required of them, was not usually defended. Urmson thus proposed that we henceforth use the religious term "saint" (etymologically, a holy person) to refer to those who live lives of supererogatory moral goodness. And from this point onward, this moral, secular use of "saint" became commonplace in Anglophone philosophical discourse to refer to such individuals. ${ }^{5}$

Crucially, however, as we have seen, for Singer, effective altruists are not saints in Urmson's distinctive moral sense precisely because EA (at least in Singer's view) is not supererogatory. Rather, it is morally required. That is to say, the apparently extreme or radical sacrifices of time and money that EA calls for are in fact obligatory and thus a matter of duty. Those committed to EA are therefore not saints in Urmson's sense. Furthermore, as Singer indicates above, even those who are committed to EA rarely if ever live up to the full implications of their own moral ideals, even as they accept them as obligatory. The obligations of EA thus call for continual moral striving

4 Urmson, "Saints and Heroes," 199-200. In what follows I focus only on Urmsonian sainthood, but the heroic is an important category that requires treatment as well.

5 Urmson's paper generated a substantial secondary literature; for further discussion, see Flescher, Heroes, Saints, and Ordinary Morality, and Heyd, "Supererogation." 
beyond what most of us are able to accomplish. But if the Urmsonian definition of a saint is a person who lives a life of supererogatory moral goodness, and if such goodness is impossible, then so are saints. ${ }^{6}$

To see the connection with Urmson more clearly, it is important to note that while Singer does not mention him in The Most Good You Can Do, Urmson's "Saints and Heroes" is a major focus in Singer's own classic essay, "Famine, Affluence, and Morality" - one of the early sources of EA. "Saints and Heroes" is, in fact, the only recent philosophical text cited by Singer in this essay. ${ }^{7}$ While Singer does not here comment on Urmson's moral use of "saint", he fears that Urmson's general defence of supererogatory actions might be applied specifically toward the typical (low) level of charitable donations to humanitarian relief made by citizens of affluent Western countries. Singer says that if one accepts his proposed moral principle namely, that "if it is in our power to prevent something very bad from happening, without thereby sacrificing anything else morally significant, we ought, morally, to do it" - then "the traditional distinction between duty and charity cannot be drawn, or at least, not in the place we normally draw it." 8

Further on Singer explicitly denies that ordinary levels of charitable giving in Western societies are supererogatory. However, he describes his article as an "attack on the present distinction between duty and charity," not necessarily on the distinction itself, which he here leaves as an open

6 I am grateful to Stanley Hauerwas for helping me formulate this point. However, two other commentators on this paper disagreed over whether Singer's developing position over the years in fact allowed for supererogation (and thus sainthood) at all. As one of them wrote, "If it is our duty to live ethically ideally - e.g., to maximise good consequences - there are no actions beyond duty. And if there are no actions beyond duty, there is no supererogation. And if there is no supererogation, there is no sainthood in the sense of acting supererogatorily. There is only sainthood in a different sense: in the sense of acting ethically ideally. Singer can, however, be understood to make room for supererogation by distinguishing between a 'minimally acceptable' and a 'fully ethical' life... Saints understood as people who act supererogatorily can then be understood as going beyond duty where duty is understood to merely require leading a 'minimally acceptable' life." This tension or ambiguity in Singer's position will return throughout this paper.

7 In addition to Urmson, "Saints and Heroes", and the Shorter Oxford English Dictionary, Singer only cites one work each by Henry Sidgwick, Thomas Aquinas, John Kenneth Galbraith, and E. J. Mishan.

8 Singer, "Famine, Affluence, and Morality," 235.

9 Ibid., 235-36. 
if dubious question. ${ }^{10}$ But the baneful influence of Urmson's argument, he says,

"may explain the origin and continued existence of the present division between acts of duty and acts of charity. Moral attitudes are shaped by the needs of society, and no doubt society needs people who will observe the rules that make social existence tolerable. From the point of view of a particular society, it is essential to prevent violations of norms against killing, stealing, and so on. It is quite inessential, however, to help people outside one's own society." ${ }^{11}$

Singer continues that while such considerations may explain the "common distinction between duty and supererogation," they do not justify it: "from the moral point of view, the prevention of the starvation of millions of people outside our society must be considered at least as pressing as the upholding of property norms within our society." 12

I have quoted from this essay at some length to make not just a conceptual but a textual point. While Singer does not use the term "supererogation" in The Most Good You Can Do, his earlier suspicions regarding supererogation in "Famine, Affluence, and Morality" remain crucial to his later defence of EA. Thus, in the book's preface, he writes:

"Effective altruism is based on a very simple idea: we should do the most good we can. Obeying the usual rules about not stealing, cheating, hurting, and killing is not enough, or at least not enough for those of us who have the great good fortune to live in material comfort, who can feed, house, and clothe ourselves and our families and still have money or time to spare. Living a minimally acceptable ethical life involves using a substantial part of our spare resources to make the world a better place. Living a fully ethical life involves doing the most good we can."13

The verbal similarity to the preceding passages from "Famine, Affluence, and Morality" is striking: Singer is clearly drawing on that earlier material to define the more recent EA movement. Moreover, Singer's language of "minimally acceptable ethical life" and "fully ethical life" assumes (rightly or wrongly) both that (i) we can fix the meaning of these terms with some precision and that (ii), contra Urmson, we have a duty to be not just ethical but as ethical as we can be. The project of EA further argues with

10 Ibid., 238.

11 Ibid., 236-37.

12 Ibid., 237. In addition to the texts cited in note 5, see MacFarquhar's "Duty! Thou Sublime and Mighty Name that Dost Embrace Nothing Charming or Insinuating, but Requires Submission" Strangers Drowning, 61-69; the chapter's long title is a quotation from Kant's Critique of Practical Reason.

13 Singer, Most Good, vii (emphasis added). 
yet more precision that, because doing our minimum duty by obeying "the usual rules" is insufficient to be "fully ethical," even commonly-approved forms of altruism such as donating to well-meaning but ineffective charities or supporting the arts are morally compromised. It is not enough to be altruistic, one must be effectively altruistic; one must not just do good, one must do the most good one can. In other words, in these texts, Singer comes close to the "antisupererogationist" school in which, as Todd May says, "there are essentially no limits to what morality can ask of us." ${ }^{14}$ Or, as May says of Singer himself, "it is not that there is no end to my obligations. But they don't end very soon." 15

\subsection{Singer and Wolf: Moral Saints}

While Singer's use of "saint" in The Most Good You Can Do may allude to the supererogatory Urmsonian definition, it is arguably even more indebted to another classic but much later essay, namely Susan Wolf's "Moral Saints." Here she defines an explicitly moral saint as "a person whose every action is as morally good as possible, a person, that is, who is as morally worthy as can be." 16 While Wolf does not cite Urmson's "Saints and Heroes," she is clearly contributing to the Urmsonian tradition of construing saints in secular, moral terms. However, Wolf's distinctive contribution is to then argue famously that "moral perfection, in the sense of moral saintliness, does not constitute a model of personal well-being toward which it would be particularly rational or good or desirable for a human being to strive." ${ }^{17}$ In other words, rather than commending such maximising moral sainthood, as Singer does, Wolf laments it. As Wolf explains further: "a necessary condition of moral sainthood would be that one's life be dominated by a commitment to improving the welfare of others or of society as a whole." 18 She divides such moral saints into two categories: the utilitarian "Loving Saint" (whose happiness "would truly lie in the happiness of others") and

14 May, A Decent Life, 77.

15 Ibid., discussing Kagan, Limits of Morality; and 13, discussing Singer, Most Good. As May's comments here indicate, and as previously noted in footnote 6, readers of Singer remain at odds over just what he means by a "fully ethical life" and therefore what the detailed implications of being as ethical as we can be entail in practice.

16 Wolf, "Moral Saints", reprinted in Wolf, Variety of Values, 11-29: I will cite from this reprinted version, and this quotation is from 11.

17 Wolf, Variety of Values, 11 (emphasis added).

18 Ibid., 12. 
the Kantian "Rational Saint" (who "sacrifices his own interests to the interests of others, and feels the sacrifice as such"). ${ }^{19}$

Wolf's concern with moral sainthood is that an exclusive focus on morality is "apt to crowd out the nonmoral virtues, as well as many of the interests and personal characteristics that we generally think contribute to a healthy, well-rounded, richly developed character." ${ }^{20}$ For the moral saint all nonmoral excellences, such as literature, music, art, gourmet food, wit (especially sarcasm and satire), games, and athletic ability, must be measured "against possible alternative beneficent ends to which these resources [i.e., of time, energy, and money] might be put"; therefore, engaging in such nonmoral activities requires "the decision not to justify every activity against morally beneficial alternatives, and this is a decision a moral saint will never make."21 And, vis-à-vis both Urmson and Singer, Wolf notes that if "we have reason to want people to live lives that are not morally perfect, then any plausible moral theory must make use of some conception of supererogation." 22 Just as Singer fears, then, Wolf insists that supererogation is what rightly separates the rest of us from moral saints: we need to know when we have done enough morally and feel free to stop there. There are genuine goods other than moral goods, and we cannot allow the legitimate but limited claims of morality to dominate our lives. ${ }^{23}$

Singer does not cite Wolf in The Most Good You Can Do, but it is difficult to think that he was not alluding to her "Moral Saints" when he said that, unlike saints, effective altruists "don't seek to maximize the good in every single thing they do" and "leave themselves time and resources to relax and do what they want." 24 These descriptions have a suspiciously Wolfian character. By explicitly disavowing the label of "saint" for effective altruists, it seems that Singer is claiming implicitly that they are not subject to Wolf's

19 Ibid.

20 Ibid., 12-13.

21 Ibid., 14 (emphasis in the original).

22 Ibid., 28.

23 Like the essays by Urmson and Singer, Wolf's "Moral Saints" has generated an enormous amount of commentary: for a particularly searching critical analysis, see Carbonell, "What Moral Saints Look Like." By contrast, May's A Decent Life, largely written in response to Singer, Most Good, sides with Wolf against Singer and Kagan: what is morally required of us is decency, not supererogation, and by "decency" May understands a substantial but limited moral commitment to help others. See also MacFarquhar, Strangers Drowning, 6-7.

24 Singer acknowledges her argument elsewhere and describes it as a "forceful article" (Practical Ethics, 212-13). 
critique of moral sainthood. Singer and Wolf thus apparently agree on the meaning of "saint" in this secular philosophical context but differ radically on its evaluation and exemplification. Singer clearly approves of those who seek to live "a fully ethical life" even if most effective altruists do not reach that lofty ("saintly") standard, while Wolf regards such an enterprise as inhumane and oppressive, even a type of moral fanaticism. ${ }^{25}$ That is, unlike Singer, Wolf believes in supererogation, so she can also believe in saints, at least moral ones, even if she disapproves of them.

Likewise, and for the same reason, Singer and Wolf apparently agree on the basic meaning of supererogation but evaluate it differently. As I said earlier, for Singer effective altruists are not saints in Urmson's moral sense precisely because EA is not supererogatory, and indeed as already noted for Singer supererogation itself may be an "empty category." 26 However, Singer's protests notwithstanding, I think that Wolf would regard the EA movement as indeed exemplifying a form of supererogatory moral sainthood or at least striving toward it in a worrisome manner. Like her moral saints, effective altruists are "dominated by a commitment to improving the welfare of others or of society as a whole" and "justify every activity against morally beneficial alternative.” Although EA formally began in 2009 and Wolf's essay was first published in 1982, you could not ask for a better brief description of EA than these two phrases.

In this section, I have sought to trace the technical definition of "saint" in Anglophone moral philosophy through three authors: J. O. Urmson, Susan Wolf, and Peter Singer. For Urmson, saints are those who perform supererogatory acts, that is, acts that are morally commendable but not required. For Wolf, this Urmsonian definition is taken further but then criticised: moral saints are those "whose every action is as morally good as possible," persons who are "as morally worthy as can be"; but while such extreme commitment is indeed supererogatory, it is not commendable and should thus be avoided. And as for Singer, he seems to accept Wolf's definition of sainthood, but to deny that it ever obtains, either because no one, in fact, lives up to it, or because it is impossible to exceed our moral duties and thus act supererogatorily. To again quote from The Most Good You Can Do, "most effective altruists are not saints, but ordinary people like you and me, so very few effective altruists claim to live a fully ethical

26 I am indebted to Kian Mintz-Woo for this apt phrase in this context. 
life. Most of them are somewhere on the continuum between a minimally acceptable ethical life and a fully ethical life." 27

\section{2. "The Actuality of Sainthood"}

The previous section thus raises two connected questions but leaves them unanswered: (1) Are effective altruists saints? and (2) Is EA supererogatory? Singer would reply "no" to both, whereas Wolf would reply that effective altruists are at least aspiring toward moral sainthood and that in so doing both they and their movement are committed to supererogation. For both Singer and Wolf, saints (if they exist) exemplify supererogatory altruism. However, one of my primary goals in this essay is to rescue sainthood from its Urmsonian and Wolfian captivity by moral philosophy and hence from an exclusively secular, ethical, and supererogatory context. As noted earlier, the original meaning of "saint" is not a moral person but a holy person, and while morality and holiness are intimately connected, they are not identical. I thus now wish to enlist Robert Merrihew Adams against Urmson, Singer, and Wolf, and then in the following section explore the potential implications of human holiness for both EA and religious belief.

In his classic response to Wolf's "Moral Saints," Adams dissents from her negative understanding of sainthood and presents what he thinks is the more complicated, interesting, and compelling reality. ${ }^{28}$ Adams asserts: "the first thing to be said is that there are saints - people like St Francis of Assisi and Gandhi and Mother Teresa - and they are quite different from what Wolf thinks a moral saint would be." 29 Adams grants that while such figures "are not exactly moral saints in Wolf's sense", nevertheless she "writes about some of them as if they were, and discussions of moral sainthood surely owe to the real saints much of their grip on our attention. So it will be to the point to contrast the actuality of sainthood with Wolf's picture of the moral saint." 30 It is Adams's insistence on the "actuality of sainthood" that I wish to lift up in this context. And in "Moral Saints" Wolf indeed mentions Francis, Gandhi, and Teresa as examples of what she has in mind. ${ }^{31}$ But

27 Singer, Most Good, viii.

28 Adams, "Saints," reprinted in Adams, Virtue of Faith, 164-73: citations of this essay will be from the reprinted version. Adams is Presbyterian rather than Roman Catholic, Orthodox, or Anglican, so his interest in these themes is less typical of his tradition.

29 Adams, Virtue of Faith, 164.

30 Ibid.

31 See, Wolf, Variety of Values, 14 (Francis), 23 (Mother Teresa), and 26, note 4 (Gandhi). 
against Wolf's generic depiction of moral saints as unattractive, lacking in individuality, and "dull-witted or humorless or bland", Adams simply says, "the real saints are not like that." 32 Rather than lacking individuality, saints are often eccentric, and rather than being "very, very nice" saints are often "very, very truthful" - even when that truthfulness causes trouble for themselves or others. ${ }^{33}$ Real saints, says Adams, "may not enjoy all the same things as other people, and perhaps a few of them have been melancholy, but an exceptional capacity for joy is more characteristic of them." Indeed, he continues, "there are joys (and not minor ones) that only saints can know. And as for attractiveness, the people we think of first as saints were plainly people who were intensely interesting to almost everyone who had anything to do with them, and immensely attractive to at least a large proportion of those people." 34

Adams acknowledges that real saints are often "devoted to improving the lives and circumstances of other people" and that there is indeed "unusual moral goodness in the saints," but he denies that ethical or political concerns are their primary motivation, for (he says) "sainthood is essentially a religious phenomenon, and even so political a saint as Gandhi saw his powerful humanitarian concern in the context of a more comprehensive devotion to God." 35 What Adams calls the "substance of sainthood" is not "sheer willpower striving...to accomplish a boundless task" but "goodness overflowing from a boundless source. Or so, at least, the saints perceive it." 36 In a key passage, Adams argues:

"If sainthood is essentially a religious phenomenon...it is reasonable to seek its central feature (at least for theistic religions) in the saint's relation to God. 'Saint' means 'holy' - indeed, they are the same word in most European languages. Saints are people in whom the holy or divine can be seen. In a religious view, they are people who submit themselves, in faith, to God, not only loving him but also letting his love possess them, so that it works through them and shines through

32 In comments on an earlier version of this essay, Andrew Thompson asked, "What is Adams's definition of a 'real saint' - is it sort of inductive, like his idea of Good in Finite and Infinite Goods? It seems to be, where Wolf's definition seems to be primarily deductive. And, in the end, there doesn't seem to be much overlap at all." I will address these important questions and concerns all too briefly. For Adams, Finite and Infinite Goods, see note 49 below.

33 For these specific charges, see, Wolf, Variety of Values, 14.

34 All citations from Adams, Virtue of Faith, 165.

35 Ibid., 168.

36 Ibid. 
them to other people. What other interests a saint may have will then depend on what interests God has, for sainthood is a participation in God's interests." 37

While there is much to say about how Adams's religious view of sainthood contrasts with the secular moral concept shared broadly by Urmson, Singer, and Wolf, let me here simply state that Adams's essay offers another category, which we may call the charismatic saint. ${ }^{38}$ Singer denies that effective altruists are necessarily saints, whereas Adams denies that saints are necessarily effective altruists. One need not be an effective (or ineffective!) altruist to be a saint. For Adams, saints are not characterised solely or even primarily by altruistic interests and activities, supererogatory or otherwise, but are joyful, attractive, interesting, compelling, distinctive and even eccentric individuals possessed by divine love who radiate "unusual moral goodness" and compassion embodied through their very person or self, not simply in their actions. Against Wolf's concern that moral saints must "justify every activity against morally beneficial alternatives" - a concern that she would also have about EA - Adams argues crucially that, while sainthood is indeed "participation in God's interests," God's own interests extend beyond morality or even religion. ${ }^{39}$ If, in the memorable words of Hugh Lister, God is not a "religious maniac," then God is not a "moral fanatic" either. ${ }^{40}$ Adams thus suggests that in addition to more conventional figures we might also consider Fra Angelico, Johann Sebastian Bach, and perhaps even Vincent Van Gogh as saints. In short, the charismatic saint is not simply moral, and perhaps not even moral in any conventional sense, but holy. ${ }^{41}$

\section{Real Saints, Exemplars, and Hagiological Admiration}

The exchange between Wolf and Adams is well-known in discussions of moral sainthood, but I suggest that it has acquired new significance in light of the recent rise of EA and the various debates that EA has provoked in secular and religious circles, as well as within both philosophy and

37 Ibid., 170.

38 I take the term but not the meaning from Coleman, "Transgressing the Self." Coleman's essay is about the Pentecostal and Charismatic movements of American Christianity; I mean "charismatic" in a more generic sense. See also Flescher, Heroes, Saints, and Ordinary Morality, 209.

39 Adams, Virtue of Faith, 170.

40 Cited by Hein, "Farrer on Friendship," 144 (note 20). See, Wolf, Variety of Values, 16.

41 See, Adams, Virtue of Faith, 170. For some philosophical implications of both divine and human holiness, see MacSwain, "Holiness" (forthcoming). 
philanthropy. ${ }^{42}$ Wolf's arguments can be and already have been applied to at least some versions of EA, and Singer is arguably responding to her critique in his denial that effective altruists are necessarily saints. But the EA-related renewal of interest in Wolf's "Moral Saints" means that Adams's reply to her is also newly au courant. Moreover, Adams helps us see that, despite their different evaluations of such sainthood, Singer and Wolf still share a single concept of it. Ironically, this means that even Wolf with her strong interest in defending a variety of values, including nonmoral ones, is apparently unwilling to consider a nonmoral aspect of sainthood itself, namely the holy or sacred. This is where Adams, as a Christian philosopher, helps shift the debate about sainthood out of a purely secular plane to where any legitimate discussion of saints arguably belongs, the domain of the divine. ${ }^{43}$

By contrast, Vanessa Carbonell agrees with Adams that "real saints" are not like Wolf's unattractive depiction, but she prefers to "challenge Wolf's thesis about the attractiveness of moral saints without departing from her underlying conception of a moral saint as a truly extraordinary moral agent, an agent whose uncommon qualities and achievements are not essentially religious." 44 "Adams thinks the solution is to return sainthood to its religious roots", Carbonell says, but "the sort of saint Adams describes is not necessarily a moral saint. While various historical examples of religious saints might turn out to be moral saints as well, moral sainthood is something that we can describe without reference to the holy or the divine." ${ }^{4}$ As noted above, Adams grants this point in advance, but also defends his

42 For a secular philosophical analysis of sainthood engaging with Wolf, Adams, and many others that I read after finishing this paper, but which contains much that I agree with, see the prologue to Flanagan, Varieties of Moral Personality, 1-12. Ironically, and for many controversially, Singer himself is here regarded as a saintly figure (6-7)! See chapter 4 of Flescher, Heroes, Saints, and Ordinary Morality, for an account of sainthood I am in large agreement with as well: my main difference from him is that, like Flanagan, he remains on the secular plane. An important treatment of moral sainthood that I do not discuss in this essay due to its different philosophical idiom is Wyschogrod, Saints and Postmodernism; her Levinasian view of sainthood influenced Flescher's account.

43 Another reason to engage with Adams on saints is that they are still surprisingly neglected by philosophers, and even philosophers of religion. For two exceptions, see Sherry, "Philosophy and the Saints," and Cottingham, "Saints and Saintliness."

44 Carbonell, "What Moral Saints Look Like," 376 (emphasis in the original).

45 Ibid., 376, note 1 (emphasis in the original). As her "attractive counter-example" of a real moral saint, Carbonell proposes the altruistic physician, anthropologist, and activist Paul Farmer. 
approach by observing that (i) Wolf mentions religious saints in her essay and (ii) "discussions of moral sainthood surely owe to the real saints much of their grip on our attention" - where "real saints" are taken to mean exemplary figures in whom, as Adams puts it, "the holy or divine can be seen" even if they are not conventionally religious themselves. While endorsing Carbonell's approach to "real moral saints" as worthwhile, and even convincing simply as a response to Wolf, I think she evades Adams's broader proposal too quickly. Why, after all, did the moral, philosophical, Urmsonian meaning of "saint" find such wide appeal to begin with if not for the strong positive association, moral and otherwise, with religious saints? At the very least, there is something parasitic in the philosophical idea of moral sainthood that even now still depends on religious sainthood for much of its resonance and power.

But what is a "real saint"? How are they defined? How are they recognised? What is holiness, and what, indeed, is divinity? To answer these questions fully would of course take us far beyond the confines of this essay, but at least an initial answer has already been made. Religious traditions and communities have always had exemplary figures whose function we might call canonical. Some of these figures have this status in terms of formal institutional acknowledgement; for others it is more a matter of popular devotion or esteem. ${ }^{46}$ So when it comes to "real saints" my first point is that such individuals are not necessarily moral saints in Wolf's maximising sense. In other words, to introduce yet another category of sainthood beyond the moral and charismatic, they might be what Jean Porter has called a "flawed saint." Her example is Martin Luther King, Jr, of whom she says, "whatever else he may teach us, he helps us to see that to be a saint is not to be morally perfect, but to be exemplary in love." 47

My second point is that in seeking to come to grips with real saints we should focus our attention more on what I have called charismatic saints. In their introduction to Saints: Faith Without Borders, Françoise Meltzer and Jaś Elsner associate saints with excess, marginality, and even transgression: "there is a fundamentally apophatic aspect to the excess that is embodied in the saint. Excess of this kind has been called grace, miracle, mysterious

46 See, Six-Means, "Saints and Teachers." This claim does not address all of Thompson's question about defining saints in note 32 , but is where I would begin: namely, with the recognition of saints in actual communities of faith and practice, and so inductively rather than deductively.

47 See, Porter, "Virtue and Sin," 539. As I discuss briefly in note 65 below, it is possible that Jean Vanier might fit within this category as well, but that remains to be seen. 
energy, charisma, jouissance, the Real." 48 And even the goodness of such charismatic saints can be deeply troubling and counter-intuitive. In his study Finite and Infinite Goods, Adams writes:

"What theists most admire, even within human life, is not easily identified as
normal and natural. The saints are occasionally flourishing specimens of humanity
in all the obvious ways, but usually not. They feel compunctions, and are torn
by doubts, that others do not know. They cling to a longing for goods that lie
beyond any ordinary human possibility of attainment. Their behaviour seems occa-
sionally bizarre, and often unnatural. Kissing lepers and praying for people who are
torturing you definitely do not seem natural responses. Indeed, I think it is often
precisely in the unnaturalness, or better the supernaturalness, of the saints' goodness
that their wonderfulness is found. In them it seems that we can glimpse or touch a
goodness that is more than theirs, a superhuman, a transcendent goodness that we
too long for."

Rather than Singer's "moral point of view", charismatic saints take the divine point of view, which ironically enough is not necessarily identical with what philosophers sometimes call the "God's eye point of view" of ethics. ${ }^{50}$ By the divine point of view I mean not only that, as Adams said earlier, "sainthood is a participation in God's interests," but also that, rather than heeding an abstract and universal sense of duty or justice, saints simply do what they are uniquely called to do, whatever that may happen to be. Charismatic sainthood is thus less tied to supererogation as it is to vocation. ${ }^{51}$ Saints are not called to go above and beyond the call of duty, they are called to be themselves. In the famous words of Thomas Merton, "for me to be a saint means to be myself. Therefore, the problem of sanctity and salvation is, in fact, the problem of finding out who I am and of discovering my true self." 52 To be sure, we are all called to be ourselves,

48 See their introduction to Saints: Faith Without Borders, ix-x. The literature on saints in theology and religious studies is of course vast, but for one helpful analysis see Brown, Discipleship and Imagination, 62-101. Despite the title, Orsuto, "The Saint as Moral Paradigm," takes a broader, more theological view than the purely ethical.

49 Adams, Finite and Infinite Goods, 52-53. Such saintly goodness may indeed be supererogatory, but as Adams notes it is also superhumanly transcendent. See also, Flescher, Heroes, Saints, and Ordinary Morality, 174.

50 See Taliaferro, "A God's Eye View," and Anderson, "God's Eye Point of View."

51 Vocation is of course a hugely complex and contested concept, almost as vexed as supererogation and sainthood. Chapter 13 in Adams, Finite and Infinite Goods, 292314, focuses on this topic, partly based on an earlier article, Adams, "Vocation." Heyd considers the relation between supererogation and vocation his article cited in note 5, saying that connecting them goes back to Aquinas.

52 Merton, New Seeds of Contemplation, 31. 
but saints are those who actually solve this problem, discern and heed that divine call, and fulfil it in ways that provoke admiration, astonishment, and awe.

My third and final point about real saints is to agree with Larissa MacFarquhar when she writes: "in the abstract, there are ideas about saints and perfection. Only actual lives convey fully and in a visceral way the beauty and cost of a certain kind of life." 53 Hence her book Strangers Drowning, which explores the theme of altruism, both effective and otherwise, through a series of case studies. Ironically, this approach is something that Singer also understands quite well. Thus, The Most Good You Can Do has an explicitly hagiographic character. Chapter 1 begins by telling the story of Matt Wage, a gifted Princeton philosophy student who decided to forgo graduate studies at Oxford and a potential academic career in order to work on Wall Street so that he could give away considerably more money than otherwise. Having presented Matt as an inspiring exemplar of EA, Singer promises that in the book "we will meet people" who have done similar things: Zell Kravinsky, Toby Ord, Will MacAskill, Julia Wise, Aaron Moore, Bernadette Young, Rhema Hokama, and many others. ${ }^{54}$ While disavowing the label "saint" for these exemplars of EA, they do in fact function in Singer's narrative argument as canonical figures whose lives provide both material content and inspirational justification for the tenets of EA.

Exemplars are currently a major topic of interest in philosophy, theology, and anthropology. According to the philosopher Linda Trinkaus Zagzebski, "exemplars not only show us what morality is, but they make us want to be moral and they show us how to do it." 55 Crucial to her theory of exemplarity is the experience of admiration refined by critical reflection as a means of moral knowledge. ${ }^{56}$ But Singer's list of admired EA exemplars raises the crucial question of contrasting values between the strongly rationalist-consequentialist mindset of secular EA and traditional religious morality - as found, for example, in Christianity - and thus of different canonical figures as well. For just one Christian example, consider Jean Vanier, the founder of L'Arche, who died on 7 May 2019. A lay Roman Catholic trained in philosophy, Vanier was widely revered during

53 Citation from MacFarquhar, Strangers Drowning, 11.

54 Singer, Most Good, 3-4, and passim. Some of Singer's exemplars are also included in Strangers Drowning.

55 Zagzebski, Exemplarist Moral Theory, 129. For a similar proposal from an anthropologist, see Robbins, "Where in the World Are Values?"

56 Ibid., Chapter 2. 
his lifetime for placing a profoundly high value on and exhibiting a deep respect for those with cognitive disabilities. He created radically hospitable communities in which such individuals lived as full members alongside those without such disabilities. In Zagzebski's Exemplarist Moral Theory, she offers three types of exemplar, the Hero, the Sage, and the Saint, identifying saints primarily with compassion, and Vanier is her exemplar of the Saint. Her book concludes as follows:

"Vanier has spent the greater part of his life centred on bringing love and joy to people who have it least. He is an exemplar of a joyful moral life. I have tried in this book to show a way that we can map the moral domain around people like him, while enjoying the process of making ourselves more like the exemplars who inspire us most." 57

Likewise, the theologian Stanley Hauerwas has written extensively on the significance of Vanier's life and work not only for the moral life but for belief in God. ${ }^{58}$ The witness of Vanier and L'Arche, says Hauerwas, helps us to see that we are all "creatures drawn into a kingdom of patience making possible our friendship with God and one another." 59 As inhabitants of this kingdom of patience, Christians have learned that "there is nothing more significant to be done in a world of such deep injustice than to take the time to be friends with the handicapped. I know of no better vision of peace." 60

But from the perspective of Singer and secular EA (recognising that there are religious versions that modify it in various ways ${ }^{61}$ ), Vanier cannot be admired and thus recognised as a moral exemplar, let alone a saint; L'Arche cannot be commended as a worthwhile undertaking or investment for those who seek to do the most good they can; and our world of deep injustice cannot allow us legitimately to take time (let alone a lifetime) for such ineffective activities as helping someone with Downs' Syndrome put together a puzzle or a person with physical disabilities brush their hair when we could be doing much more good elsewhere. Even if living at a L'Arche community is "good," it is not doing "the most good you can do," and

57 Ibid., 235.

58 See, for example, Hauerwas, "Timeful Friends," and Hauerwas, "God and Goodness." See also the book co-authored by Hauerwas and Vanier, Living Gently in a Violent World.

59 Hauerwas, "Reflection on Dependency," 193.

60 Ibid., 197. For an earlier engagement with this material, see MacSwain, "Imperfect Lives and Perfect Love."

61 For example, EA for Christians (https://www.eaforchristians.org). 
therefore those who commit themselves to it are not seeking to live "a fully ethical life." As the populariser of the term "speciesism," Singer does not take it for granted that humans - or, for that matter, creatures of any other species - have inherent value. The correct value ascribed to a human being depends on factors such as cognitive ability, agency, or ability to suffer. Thus, according to Singer, it remains an open question of how valuable the lives of people with disabilities are, especially if they score low according to criteria such as cognitive ability. To regard the cognitively disabled as in fact deserving special esteem and privileged treatment is, therefore, a sentimental fallacy of the first order. ${ }^{62}$

So, what accounts for these vast differences of evaluation between Singer on the one hand and Zagzebski and Hauerwas on the other? Why do they have such different "hagiological intuitions" and thus admire such divergent exemplars? There are, of course, no simple answers to these questions, but part of the difference surely has to do with moral vision. Christian thinkers such as Zagzebski and Hauerwas do not simply think differently than Singer, they see the world in a radically different way, and thus inhabit it differently as well. As Hauerwas insists, such vision requires training, and such training requires learning proper description. One of his maxims, inspired by Iris Murdoch, is "You can only act in the world you can see and you can only see what you have learned to say." 63 Vanier, Hauerwas would say, is one of those who has taught us to describe and see the cognitively disabled properly, and therefore to see the world properly as well. Indeed, anthropologist Patrick McKearney goes so far as to suggest that the genuine saints of L'Arche are the cognitively disabled residents themselves. He writes:

"I show that carers in L'Arche are trained to recognise those with cognitive disabilities not as humans who lack autonomous moral agency, but as people who inhabit the world in a different way. That is, they learn to see people with cognitive

62 I am grateful to the editors for helping me formulate Singer's position here more fairly than in my original draft. For a probing and sensitive engagement on this theme, see Hopwood, “Terrible Purity.” Note, however, that when Peter Singer's mother developed advanced Alzheimer's, Singer, in violation of his theories about both giving and personhood, spent a lot of money paying nurses to take care of her. "Perhaps it is more difficult than I thought before," he said, "because it is different when it's your mother" (MacFarquhar, Strangers Drowning, 101).

63 Hauerwas says this in various places; one example is Hauerwas, Work of Theology, 26. 
disabilities as surprising, eccentric and charismatic agents who can powerfully affect the ethical lives of others." 64

I know of no better description of saints. ${ }^{65}$

\section{Conclusion}

The premise of this volume is that EA has secular roots and yet is of profound religious significance, such that religious practitioners should ask themselves both what they can learn from EA and what within it might require critique or resistance. I have personally been challenged by EA to reconsider some of my basic religious and ethical convictions, and I am still in the process of doing so. ${ }^{66}$ But in regard to the primary question of this essay, Are effective altruists saints?, my answer is that it depends. It

64 McKearney, "Receiving the Gift of Cognitive Disability," 41. See also the section aptly titled "Exemplars of intuition and charisma," 53-55.

65 On 22 February 2020, L'Arche International released a summary report of a posthumous investigation concluding that there was "sufficient evidence to establish that Jean Vanier engaged in manipulative sexual relationships with at least 6 adult (not disabled) women" over a thirty-year span. This disturbing revelation obviously requires rethinking much of the material cited above, and in particular the exemplary use of Vanier made by Zagzebski and Hauerwas (along with many others not cited here). The implications of Vanier's moral fall are immense and remain to be fully understood. His actions were deeply wrong, harmful, and inconsistent with his own articulated moral vision and values. And yet these tremendous failings were compatible with him also accomplishing immense good on behalf of the physically and mentally disabled and changing the way that thousands of people think of them and their place in human society. It is too soon to begin the discussion, but at some point we will have to inquire whether Vanier might fit along with Martin Luther King Jr under Porter's "flawed saint" category, or if even that is insufficient to account for his failings. Given that this essay was written before and yet published after these revelations, all I can do at the moment is add this footnote to acknowledge this new information, and yet also point to McKearney's important distinction between Vanier himself (including his personal writings and teachings) and the exemplary life of the L'Arche communities he founded, specifically the virtues of the carers and residents.

66 Some of the questions EA has raised for me are: (1) What is the moral status of the traditional "helping professions" compared to EA's "earning to give"? That is, is it better to do good yourself or pay others to do good on your behalf? (2) What is the difference between "being good" (character) and "doing good" (utility), and which if either is better? (3) Is it morally permissible to financially support religious institutions? That is, even for those who are faithful believing members of a religious community, should they give money to their church, synagogue, mosque, or temple, or to one of the EA-approved charities instead? And (4) How much more should I donate to charity than I currently do, and should I change the focus of my giving in a more EA direction? 
first depends on what we choose to mean by "saint" and I do not wish to be bound by the moral categories of Urmsonian or Wolfian sainthood. ${ }^{67}$ But if I am correct that saints properly understood do what they are uniquely called to do, whatever that may happen to be, then the answer to this question also depends on such vocational discernment. Some effective altruists may well indeed be saints, but not necessarily because they are effective altruists. It depends on what they are called to be and do by God (whether they believe in God or not) given their particular circumstances, history, abilities, and all the other contingent factors that go into a vocation. If we inhabit Hauerwas's divine "kingdom of patience," then "they also serve who only stand and wait" (Milton), in which case any number of "ineffective" roles may serve as paths of sainthood, including living in a L'Arche community.

In regard to the secondary question of the essay, Is EA supererogatory?, my answer is also that it depends. Andrew Michael Flescher has argued that supererogation is a flexible phenomenon, and that the line of duty varies from person to person and even changes for the same individual over the course of their lifetime, depending on their growth in moral development as well the contingent factors mentioned above. There is not a fixed objective standard of duty that is the same for all people at all times. Thus, contrary to Urmson, Singer, and Wolf, saints may indeed exist and yet not exemplify supererogation, if what they do is not supererogatory for them, given their distinct charism and particular vocation. So, it may well be the case that for some people, EA is supererogatory while for others it is obligatory. ${ }^{68}$ This is thus also a matter of individual discernment. If so, then my lingering concern with EA is less with its vision of the good and more with its vision of human nature.

Making the meaning of sainthood and the demands of supererogatory altruism matters of individual discernment does not, of course, evade the challenging conceptual and practical questions canvassed in this essay. ${ }^{69}$

67 In short, I do not think that being a saint means being a strict act utilitarian, a subjective consequentialist, or either Wolf's Loving Saint or Rational Saint.

68 See Flescher, Heroes, Saints, and Ordinary Morality, esp. Chapters 2, 4, and 5; MacFarquhar's Strangers Drowning corroborates Flescher's argument, with many of those she interviews insisting that their extreme altruism is obligatory for them.

69 I am working on a monograph currently titled The Saint is Our Evidence: The Hagiological Argument for the Existence of God which explores the idea that saints provide evidence for God and perhaps even the best evidence. One version of the hagiological argument construes saints as supreme, radical, or excessive altruists, so there is a connection to EA to be explored further there as well. 
What, in fact, is the relationship between supererogation and altruism? How much good are we as unique individuals truly obliged to do, and at what point, if any, can we say that we have gone beyond the call of our own particular duty? Is the good we are called to do necessarily the same as the most good we can do? Should we, in fact, even attempt to live a "fully ethical life" and if so what would it look like? What would motivate us to embrace such radical altruism, effective or otherwise, in the first place? And finally, what does it mean for us to "discover our true selves" so that we may become saints as well? In whatever way all of these questions are ultimately answered, the example of those we call saints will assist us in doing so. ${ }^{70}$

\section{References}

Adams, Robert Merrihew. "Saints." Journal of Philosophy 81 (1984): 392401.

York: Oxford University Press, 1987.

. "Vocation." Faith and Philosophy 4 (1987): 448-62.

Finite and Infinite Goods: A Framework for Ethics. New York: Oxford University Press, 1999.

Anderson, Pamela Sue. "What's Wrong with the God's Eye Point of View: A Constructive Feminist Critique of the Ideal Observer Theory." In Faith and Philosophical Analysis: The Impact of Analytical Philosophy on the Philosophy of Religion, ed. Harriet A. Harris and Christopher Insole, 85-99. Aldershot: Ashgate Publishing, 2005.

70 A large number of people offered comments on earlier versions of this essay and I am very grateful to them all: David Brown, Ben Cowgill, Cynthia Crysdale, Stanley Hauerwas, David Hein, Mark Hopwood, Ann Loades, Kian Mintz-Woo, Stefan Riedener, Dominic Roser, Andrew Thompson, and Leigh Vicens. I am likewise grateful to Dominic Roser and the late Markus Huppenbauer for inviting me to present it at the "Religious Perspectives on EA" workshop at the University of Fribourg, Switzerland (3-4 September 2019) and to the other workshop participants for additional comments, criticism, and conversation during the event. In addition to my home institution of the University of the South (USA), I need to thank one other academic institution and two other sources of funding. Some of this research occurred during my 2016-17 sabbatical as a visiting scholar at Harvard Divinity School, funded in part by a Post-Doctoral Faculty Fellowship from the Appalachian College Association. However, most of the research as well as my attendance at the workshop in Fribourg was made possible through the support of a 2019-20 grant from Templeton Religion Trust. The opinions expressed in this publication are those of the author and do not necessarily reflect the views of Templeton Religion Trust. 
Brown, David. Discipleship and Imagination: Christian Tradition and Truth. Oxford: Oxford University Press, 2000.

Carbonell, Vanessa. "What Moral Saints Look Like." Canadian Journal of Philosophy 39 (2009): 371-98.

Coleman, Simon. "Transgressing the Self: Making Charismatic Saints." In Saints: Faith Without Borders, ed. Françoise Meltzer and Jaś Elsner, 7395. Chicago and London: University of Chicago Press, 2011.

Cottingham, John. "Saints and Saintliness." In The Oxford Handbook of the Epistemology of Theology, ed. William J. Abraham and Frederick D. Aquino, 79-96. Oxford: Oxford University Press, 2017.

Flanagan, Owen. Varieties of Moral Personality: Ethics and Psychological Realism. Cambridge, MA: Harvard University Press, 1993.

Flescher, Andrew Michael. Heroes, Saints, and Ordinary Morality. Washington, DC: Georgetown University Press, 2003.

Hauerwas, Stanley. "Timeful Friends: Living with the Handicapped." In his Sanctify Them in the Truth: Holiness Exemplified, 143-56. Edinburgh: T\&T Clark, 1998.

. "Reflection on Dependency: A Response to Responses to My Essays on Disability." In Critical Reflections on Stanley Hauerwas' Theology of Disability: Disabling Society, Enabling Theology, ed., John Swinton, 191-97. Binghamton, NY: The Haworth Press, 2004.

with Words: On Learning to Speak Christian, 61-75. Eugene, OR: Cascade Books, 2011.

. The Work of Theology. Grand Rapids. MI: Eerdmans, 2015.

Hauerwas, Stanley and Vanier, Jean. Living Gently in a Violent World: The Prophetic Witness of Weakness. Intro. John Swinton. Downers Grove, IL: InterVarsity Press, 2008.

Hein, David. "Farrer on Friendship, Sainthood, and the Will of God." In Captured by the Crucified: The Practical Theology of Austin Farrer, ed. David Hein and Edward Hugh Henderson, 119-48. New York: T\&T Clark International, 2004.

Heyd, David. "Supererogation" The Stanford Encyclopedia of Philosophy, (Fall Edition), ed. Edward N. Zalta, 2019. https://plato.stanford.edu/archives/ fall2019/entries/supererogation/.

Hopwood, Mark. "Terrible Purity: Peter Singer, Harriet McBryde Johnson, and the Moral Significance of the Particular." Journal of the American Philosophical Association 2 (2016): 637-55. 
Kagan, Shelly. The Limits of Morality. Oxford: Oxford University Press, 1991.

MacFarquhar, Larissa. Strangers Drowning: Grappling with Impossible Idealism, Drastic Choices, and the Overpowering Urge to Help. New York: Penguin Press, 2015.

MacSwain, Robert. "Imperfect Lives and Perfect Love: Austin Farrer, Stanley Hauerwas, and the Reach of Divine Redemption." In Exchanges of Grace: Essays in Honour of Ann Loades, ed. Natalie K. Watson and Stephen Burns, 142-54. London: SCM Press, 2008.

- "Holiness." Encyclopedia of Philosophy of Religion, ed. Stewart Goetz and Charles Taliaferro. Wiley (forthcoming).

May, Todd. A Decent Life: Morality for the Rest of Us. Chicago and London: University of Chicago Press, 2019.

McKearney, Patrick. "Receiving the Gift of Cognitive Disability: Recognizing Agency in the Limits of the Rational Subject." The Cambridge Journal of Anthropology 36, no. 1 (2018): 40-60.

Meltzer, Françoise and Jaś Elsner, ed. Saints: Faith Without Borders. Chicago: University of Chicago Press, 2011.

Merton, Thomas. New Seeds of Contemplation. New York: New Directions Publishing, 1962.

Orsuto, Donna L. "The Saint as Moral Paradigm.” In Ethics and Spirituality, ed. Charles E. Curran and Lisa A. Fullam, 145-61. New York: Paulist Press, 1996.

Porter, Jean. "Virtue and Sin: The Connection of the Virtues and the Case of the Flawed Saint." The Journal of Religion 75 (1995): 521-39.

Robbins, Joel. "Where in the World Are Values? Exemplarity and Moral Motivation." In Moral Engines: Exploring the Ethical Drives in Human Life, ed. Cheryl Mattingly, Rasmus Dyring, Maria Louw, and Thomas Wentzer, 155-73. New York: Berghahn Books, 2017.

Sherry, Patrick J. "Philosophy and the Saints." The Heythrop Journal 18 (1977): 23-37.

Singer, Peter. "Famine, Affluence, and Morality." Philosophy and Public Affairs 1 (1972): 229-43. 2011.

. The Most Good You Can Do: How Effective Altruism is Changing Ideas about Living Ethically. New Haven and London: Yale University Press, 2015. 
Six-Means, Horace. "Saints and Teachers: Canons of Persons." In Canonical Theism: A Proposal for Theology and the Church, ed. William J. Abraham, Jason E. Vickers, and Natalie B. Van Kirk, 97-118. Grand Rapids, MI: Eerdmans, 2008.

Taliaferro, Charles. "A God's Eye View." In Faith and Philosophical Analysis: The Impact of Analytical Philosophy on the Philosophy of Religion, ed. by Harriet A. Harris and Christopher Insole, 76-84. Hampshire, UK: Ashgate, 2005.

Urmson, J. O. "Saints and Heroes." In Essays in Moral Philosophy, ed. A. I.

Melden, 198-216. Seattle: University of Washington Press, 1958.

Wolf, Susan. "Moral Saints." Journal of Philosophy 79 (1982): 419-39.

- The Variety of Values: Essays on Morality, Meaning, and Love. New York: Oxford University Press, 2015.

Wyschogrod, Edith. Saints and Postmodernism: Revisioning Moral Philosophy. Chicago and London: University of Chicago Press, 1990.

Zagzebski, Linda Trinkaus. Exemplarist Moral Theory. New York: Oxford University Press, 2017. 
